KYKLOS, Vol. 52 - $1999-$ Fassc. 1, 3-26

\title{
Does Growth Cause Happiness, or Does Happiness Cause Growth?
}

\author{
Charles Kenny" \\ The happiness and unhappiness of the rational. social \\ animal depends not on what he feels but on what he does; \\ just as his virtue and vice consist not in feeling but doing. \\ Marcus Alurelius, Meditations, ix, 16. \\ There is nothing which has yet been contrived by man by \\ which so much happiness is produced as by a good tavern \\ or inn.
}

Boswell. Life of Johnson, vol vi, chap iii

\section{INTRODUCTION}

The two quotes above suggest alternate ideas about the sources of happiness. The first (written around AD 180) is an Aristotelian notion. Happiness is a way of living, not a state. The second quote (written some 1500 years later) suggests ideas about the sources of happiness perhaps more akin to the way that we tend to view them today. Happiness is about conviviality, warmth, food (and perhaps some ale). Neither view, however, emphasizes the importance of wealth beyond the dreams of Croesus or Bill Gates. Further, that happiness and pleasure have been a subject of discussion since at least the earliest western philosophy suggests high levels of national income are not necessary for happiness.

Nonetheless, it is posited in much of the literature on economic growth that ever greater income leads to ever greater utility. If an economy expands, the goods produced in the now larger economy will satisfy conditions on a higher

: Consultant, The World Bank, 1818 H St, NW, Washington, DC 20433. Thanks for very helpful comments and contections to Sir Anthony Kenny. Ludly Kemy. Todd Moss. Moshe Syruuin and David Willians. The views. opinions and remiining errors are mine and do not reflect the views of the World Bank. 
indifference curve than the goods produced before. The assumption that consumers derive higher utility from being on a higher indifference curve is a fundamental of economics, and has been a commonplace across the theoretical spectrum for a long time. Smith predates the terminology used above. but for him,

the happiness of mankind seems to have been the original purpose intended by the Author of nature' (Smith 1982. p. 166),

and this happiness is furthered by the wealth of nations. More goods and more choices amongst those goods lead to greater utility, then, where utility is

"the pleasure or satisfaction derived by an individual from being in a particular situation or from consuming goods or services" (Bannock, Baxter and Davis 1987. p. 414)

- a term for what one might label a particular form of happiness.

Borrowing from and building on work' by Dusenberry (1949), Mishan (1967), Easterlin (1974), Veenhoven (1995) and Hudson (1996) (amongst others). I will argue that the marginal utility of absolute (as opposed to relative) income is much less significant than sometimes assumed, especially in richer countries. To put it another way, there is rapidly declining utility gained in expanding the production possibility frontier. This can be explained by re-examining the causes of happiness in general, taking some lessois from a conception of happiness (at least in parts) held by Smith, Mill and Bentham. This conception also suggests that happiness might even be a cause rather than a symptom of economic growth. Using poll data from the OECD countries over the last forty years, this paper argues that, if there is a link between growth and happiness, it does indeed appear to run from happiness to growth, not viceversa. The paper concludes by noting some possible theoretical and policy consequences of this.

\section{THEORY}

Everyone recognizes that GNP per capita is far from a perfect linear measure of utility per capita or happiness per capita. First, there are clearly goods and services captured in the national accounts -government output, for exanple - of which we do not know the value to consumers. Also. there are clearly goods and services not captured in the national accounts - such as lousework - and things that people want (life expectancy or a clean. sale environment for instance) for which GNP per capita is. at best, an imperfect proxy. Compare Mozambique, China and the USA. In turn, the countries' GNPs per capita in 1992 were $\$ 80$, 
DOES HAPPINESS CAUSE GROWTH?

$\$ 470$ and $\$ 24.740$. Infant mortalities were $145.6,30.5$ and 8.6 per 1.000 live births, respectively. Life expectancies were 47,69 and 76 years. Thus, going 1.6 percent of the distance between Mozambique and the United States in terms of wealth, so reaching China's income, we move 84 percent of the distance in terms of infant mortality and 76 percent of the distance in terms of life expectancy.

In the case of negative externalities, such as pollution, the link between income and growth might even be negative (as Mishan 1967. p.19, put it: "bringing the Jerusalem of economic growth to England's green and pleasant land has so far conspicuously reduced both the greenness and the pleasantness'). As the interdependence of our lives increases, so might the importance of these externalities (Abramovitz 1958, p. 11). To the extent that raising the income of all requires a process of social, political and cultural modernization, it may also be that many in society find this process more painful than the palliative effects of increased wealth (McMylor 1994). The question of modernization links to a theoretical argument against a simple connection between growth and welfare. If growth changes values, altering indifference curves, it is impossible to say a priori if we will be happier before or after growth. As an example, there are certainly examples of our attitudes toward consumption changing as the economy has grown - Abramovitz mentions an increased tendency to base value on price and an increased emphasis on conformity to group taste (1958, p. 19).

This links in with a question about the nature of utility, which has been a subject of some debate amongst economists as to its being a measure of satisfaction or of desiredness (Sen 1995, p. 13). The rational, utility-maximizing individual no doubt knows that which will satisfy him and so desire and satisfaction are interchangeable. There might be a real problem here, however: Indifference curves 'as revealed' are undoubtedly a measure of desiredness, not satisfaction. This is, perhaps, a reason why moving up indifference curves might not increase utility. If the consumer is not a rational utility maximiser with perfect knowledge, he will not necessarily increase his utility because of jumping to a higher desire-based indifference curve - like King Midas, he might be suffering from a false self-knowledge of what will increase his satisfaction.

Further, given that choice itself is not cost-free, choice anongst plentiful but similar items might have high costs in terms of production but low benefits in terms of consumption. Consumption also takes time - adding more goods if there is no time to enjoy them might be fruitless (Linder 1970, p. 8). As time rather than income becomes the binding constraint, it is likely that how we earn a living rather than what we earn will become ever nore important to our satisfaction (Abramovitz 1958). A linked complaint against GNP per capita is that for it to be a measure of al country's utility gained from income, it has to be assumed that, at the margin, an increment of income will be valued the same by all 


\section{CHARLES KENNY}

people. Within a country where there are disparities of income, this is unlikely to be true (the poor might well appreciate an extra dollar to spend more than the rich). Across countries, as it might be between Mozambique (with a GNP per capita of \$80), and the US (with a GNP per capita of \$24.740) such an assumption would be absurd (data from World Bank 1996)'. Finally, economists have long discussed the relative income hypothesis, that what matters to an individual in a rich country might be his relative not his absolute wealth (Pigou 1912, Dusenberry 1949, Easterlin 1974, Ng and Wang 1991). In part this is because there are some things that require a high relative income to buy. Only the rich will ever be able to afford servants, for example (Hirsch 1978). No amount of absolute income will land us all on the shores of Lake Woebegone.

Despite these problems, it has been widely accepted at least since Adam Smith that greater national wealth is for the greater national good. Although inequality is a complicating factor, Deininger and Squire (1996) note that it changes very slowly over time. The Kuznets hypothesis that growth could lead to greater inequality appears to be overblown. National growth, then, is likely to increase the income of all, at least to some extent. There is likely to be a diminishing marginal return to income, but it will almost certainly never be negative (even if the return to marginal income plus associated externalities might be). Thus, growth will in general increase happiness overall, by providing more goods and greater choices amongst goods. Further, Pritchett and Summers (1996) have exhaustively confirmed the conventional wisdom that there is a positive causal relationship between income and health. Pigou (1912. p.11) listed most of the broad arguments made above against a ciose relationship between happiness and growth and still concluded that

'it cannot be inaintained seriously that an increase in (absolute income) will add inothing whatever to the salisfactions which constitute economic welfare".

This is a conclusion that most economists would probably still accept.

The idea that choice amongst plenty is one fundamental of happiness has a distinguished pedigree, then. However, many fathers of economic thought and welfare economics (a subject grounded in utilitarianism) had a view of utility which suggested limits to the extent to which income could create happiness. For example, even Adam Smith seemed to accept that there was a point at which more in-

1. This is widely accepted. People appear to be more comtortable accepling that an equal percentuge change in income will lead to equal increases in happiness. This seems to be somewhat arbitrary as well. however. It still seems unlikely that a 100 percent increase in the income of the United States would be an equal cause of happiness to a doubling of the average income in Mozambique. 
come has no use. He argued that large land-holdings were inefficient because the large landholder can have no real need or desire for more money (and so would not improve the land) (Smith 1910, Book II Ch. II). Mill implicitly denied the importance of income by arguing that liberty is the surest way to the greatest good. If the most important freedom is that of men in relation to other men, the 'natural' boundaries of action are a relatively unimportant cause of ameliorable distress. Lack of technology or of national weaith matter far less than liberty trom others, then.

Both Smith and the Utilitarians did think that relative income was and would remain important, however. This was not only, or indeed primarily, because they supported the common modern arguments for the relative income hypothesis, or saw the poor as having a higher marginal utility of income because they had fewer consumer goods already. Relative income played a significant role in happiness because it would allow for the poor to be active in society. In On Liberty, Mill argued that there was an important role for government intervention to protect the poor because no locality has the right

'to make itself by mismanagement a nest of pauperism ... impairing the moral and physical condition of the whole laboring community' (Mill 1980, p. 140).

For the same reason, both Smith and Bentham supported a minimum wage, one set relative to other incomes, that would allow the poor to preserve decency in society (Rothschild 1995, p. 336 and Stabile 1996, p. 689).

The importance to happiness of preserving decency in society - and so allowing the poor to take an active role in society - was centered around the idea that happiness and virtuous activity were closely related. Both Smith and the majority of Utilitarians saw a significant link between moral behavior and happiness. For example. Mill argued that there are more and less valuable pleasures, and no intelligent, feeling man would be selfish or base - further, education should be used to ensure that men accepted the link between their own good and that of society (Stabile 1996, p. 690). More recently, Bertrand Russell, writing on The Conquest of Happiness (1930) noted that:

I have written in this book as al hedonist, that is to say, as one who regards happiness als the good. but the acts recommended lrom the point of view of the hedonist are on the whole the same as those to be recommended by the sane moralist'

Despite holding to the yardstick of the greatest pleasure for the greatest number, then, Mill and other Utilitarians recognized the importance of ease in social interaction which came about in part through income equality, and Smith, at least, explicitly recognized there was a limit to the income that could create greater happiness. In fact, these thinker did not abandon an idea of the sources of pleasure that had a decidedly Aristotelian bent. While. Aristotle held eudaimonia 


\section{CHARLES KENNY}

(doing well) rather than pleasure as the absolute good and saw individuals as no judge of their own happiness (Kenny 1992), he too disapproved of excess (Aristotle 1980), saw pleasure and virtuous activity as inseperably bound up and saw a happy citizen as a moral citizen (Aristotle 1962). Thus, the link between doing well and feeling well has survived long. Most recently, of course, a variation has seen a revival amongst economists led by Amartya Sen $(1980,1985,1992)$, although Sen travels further toward an Aristotelian definition than most Utilitarians would ${ }^{2}$. Indeed, there is now a large body of literature in economics that has attempted to model the effects of related concepts such as 'extended sympathy' on models of welfare economics (Dagum 1990).

The links between virtue, social interaction and happiness are also found increasingly attractive by those who have made recent studies of happiness. As Hudson (1996, p. 107) puts it,

the new science of happiness is slowly tracing its way back to the past'.

For example, modern polls reveal that happy people view themselves as being more moral than the average (Myers and Diener, p. 71). Veenhoven (1993, pp. 69-70) has found evidence of a correlation between trust in one's fellow man and happiness (although. interestingly, there is a negative correlation between happiness and trust in institutions). Other studies of subjects ranked by self-professed happiness found that happier subjects have a high degree of social interaction and participation in the environment (McGill 1967, p. 333). They are more likely to initiate social contact with friends, more likely to tespond to requests for help, less likely to be absent from work and less likely to be involved in disputes when at work (Frank 1997, p. 1833).

2. Sen bases lis idea of advance on 'Functionings' - the ability to do things. Thus, a person in povery is disadvantiged whatever lhey think about it. "Can we possibly believe that he is doing well just beculuse he is happy and satisfied? Can the living standard of a person be high if the life that he or she leads is rull of deprivation?" (Sen 1985. p. 8). Wilhout talling into the trap of absolute cultural relativism. and while accepting the ideid that there might be false consciousmess". I would argue that this depends on the nature of the deprivation. There are certain animal needs such ats lood, sleiter and treedom from violence the most basic of basic needs, the most primatry of primary goodsi, that only the mad - and soon dead - would be salisfied without. There are ather things bat ascally make people happier, as tar as we know (relative aducation. relative weal(h, relalise lite expectancy). But if a person is happy without them, and woukd not be made lappier witl them. is il my role to lorce them upon him? How do I know it is he. not I. who suflers liom "false consciousness"? 


\section{DOES HAPPINESS CAUSE GROWTH?}

The link between general happiness and a cooperative society provides the basis for asserting that happiness might, in fact, cause growth ${ }^{3}$. Smith suggests this: that man has a real love of virtue and refinement of manners is a necessary requisite of national opulence, he argues (Stabile 1996, p. 688). The role of trust in promoting economic growth has recently been emphasized by Fukuyama:

trust can dramatically reduce... transaction costs ... and make possible certain forms of economic organization that otherwise would be encumbered by extensive rules, contracts, litigation and bureaucracy',

he argues (Fukuyama 1995, p. 90). Granato, Inglehart and Leblang's (1996) cross-country study finds some evidence of a positive correlation of a score of 'trust in people' with economic growth (although, admittedly, a negative association between 'life satisfaction' and growth). In linked work, Narayan and Pritchett (1996) expand on Putnam's (1993) study, and find that a measure of 'social capital' (membership of community groups) is strongly and significantly related with average village income in Tanzania. They postulate this might be because of increased informational efficiencies ${ }^{+}$. As to linked work on inequality, studies tend to find a weakly significant positive link between equity and growth (Clarke 1995. Bourguignon 1996, Perotti 1995). One strand of the literature argues that equality increases trust, social and political stability, so pro-

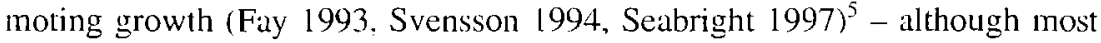
commentators posit other channels ${ }^{6}$.

Nobody would argue that increased absolute income is the unique cause of increased happiness. What the above discussion suggests is that. while there

3. Arguing thal a strong, open society with a common molal code is good for happiness and good for growth is not the same as arguing that 'all community is good'. While a sense of community might be important for every individual's happiness, the nature of that community might create positive or negative externalities for others" happiness and national growth. Communities are exclusive. It is easy to think of communities that had have been exclusive in ways that have made others miserable (lle Afrikaner volk or Hulus. lor examplel. There is also evidence that stch exclusive communities are deterrents to economic growth because they increase the complexity of public good supply (Easterly 1996).

4. Although it should be noted that another altempr to correlate 'social capital' of the Putnam type with growth produced a negative association (Helliwell 1996), while Jackman and Miller (1996) re-examined Punam"s measures of civic community and lound them weak predictors of economic pertormance.

5. Even il one accepts the Chicago School's argument that relative income inequality represients solely difterences in relative dexires for income and leisure, one could imagine that societies with such very different "Values" (as inanilested in high Cini colticient! would have lower levels of trust.

6. Dusenberry (19.49) argued that inequality led the poor to be pressured into meeting community consumption standards by reducing their savings, others point to its wole in decreasing educalional attainment (Atkinson 1997). 


\section{CHARLES KENNY}

will be many factors determining 'national happiness' (perhaps including crime, war or weather for example), average national income will be an insignificant cause in rich countries while relative income might remain significant. On the other hand, the importance of trust and equality to economic growth and the possible link between a happy society and a trusting, cohesive society suggests that there might also be a relationship that runs from happiness to greater national wealth.

\section{CROSS-COUNTRY EVIDENCE}

'Happiness' as measured in polls is designed to capture the degree to which an individual judges the overall quality of his life as a whole favorably (Veenloven 1993, p. 28). The question read out for a 'three-step' poll, for example, tends to take the form 'In general, how happy would you say you are?: very happy, fairly happy or not very happy?' (Veenhoven 1995). There are obvious questions over the validity and comparability of such polls, but they do appear to capture feelings of 'the good life'. 'satisfaction' and 'pleasure'. which ought to increase in growing economies if there is utility in increasing absolute income. Results of these polls do not appear to be random - indeed they are fairly (though not completely) constant over time. The polls also appear to fit with many of our priors. Those who say they are happy tend to appear that way to friends, family members and psychologist interviewers, and they smile more often than those who say they are unhappy. The happy have higher self-esteem and feel in control of their lives. The very rich in the US are slightly happier than average, while hospitalized alcoholics, new inmates, new psychotherapy clients, South African blacks during apartheid and students living under economic and political oppression are all reported as being less happy than average (Myers and Diener 1996, pp. 70-71). Happiness polls have already been used by a few economists before now (Blanchflower and Oswald 1992). Further, at least such polls are an attempt to measure levels of utility directly, rather than relying on an untested theory that GNP per capita is a good proxy for societal utility.

A clear problem remains that of cultural variations in propensities to see the world in a positive or negative light, or to understand the poll question in different ways (Easterlin 1995, p. 43) 7 . The figures on means and standard deviations of reported happiness scores over time in a group of western countries (Table I)

7. Veenhoven (1993) argutes that finguistic problems or culture do not play a large role in determining happiness scores (pointing to the large difference in happiness scores between the former East and West Germanies as an examplet, but it is impossible to completely discount their role. 
suggests this might be a problem with cross-country studies. The average standard deviation of happiness over time within a country is about 0.1 on a threepoint scale (with 'very happy' scoring 3, 'fairly happy' scoring 2 and 'not very happy" scoring 1). The standard deviation of the average happiness across countries is 0.19 - significantly larger. This suggests there is a large constant component (possibly cultural) in people's answers to such polls. This is why, wherever possible, I will limit my use of happiness polls io in-country temporal comparisons rather than cross-country analysis ${ }^{8}$.

Table I

Happiness in Wealthy Countries - Data Set

\begin{tabular}{lccccc}
\hline & Mean & Maximum & Minimum & Std. Dev. & Observations \\
\hline Belgium & 2.21 & 2.40 & 2.07 & 0.12 & 10 \\
Denmark & 2.25 & 2.34 & 2.09 & 0.08 & 10 \\
France & 1.92 & 2.01 & 1.84 & 0.05 & 11 \\
Ireland & 2.17 & 2.34 & 1.87 & 0.13 & 10 \\
Italy & 1.72 & 1.82 & 1.51 & 0.09 & 11 \\
Luxembourg & 2.11 & 2.20 & 2.00 & 0.08 & 10 \\
Netherlands & 2.36 & 2.48 & 2.22 & 0.07 & 11 \\
UK & 2.15 & 2.49 & 1.90 & 0.17 & 12 \\
USA & 2.25 & 2.51 & 2.13 & 0.11 & 25 \\
West Germany & 1.98 & 2.04 & 1.89 & 0.04 & 10 \\
\hline
\end{tabular}

Source: Veenhoven 1995.

8. I will also avoid comparing three-step polls on happiness with four or tive-step polls, which reyuires an arbitrary (if carefiul. and apparently guite accurate) ranking of different poll responses on a common ten-point scale. Despite this. even within polls 1 am left assuming a spurious cardinality. To check the scule of this problem. I took the happiness scores reported in Table 4 and retumed to the original polls (reported in Veenhoven 1994) to check the percentages giving each answer. In every case the percentage answering that they were not happy increased when the happiness score declined and decreased when the lappiness score rose. In all cases but one (France), the percentage answering they were very lappy decreased when the happiness score declined and increased when the happiness score rose. This suggests that the problem is not particularly large. 
CHARLES KENNY

Figure I

Happiness Against Income Across Countries, 1975

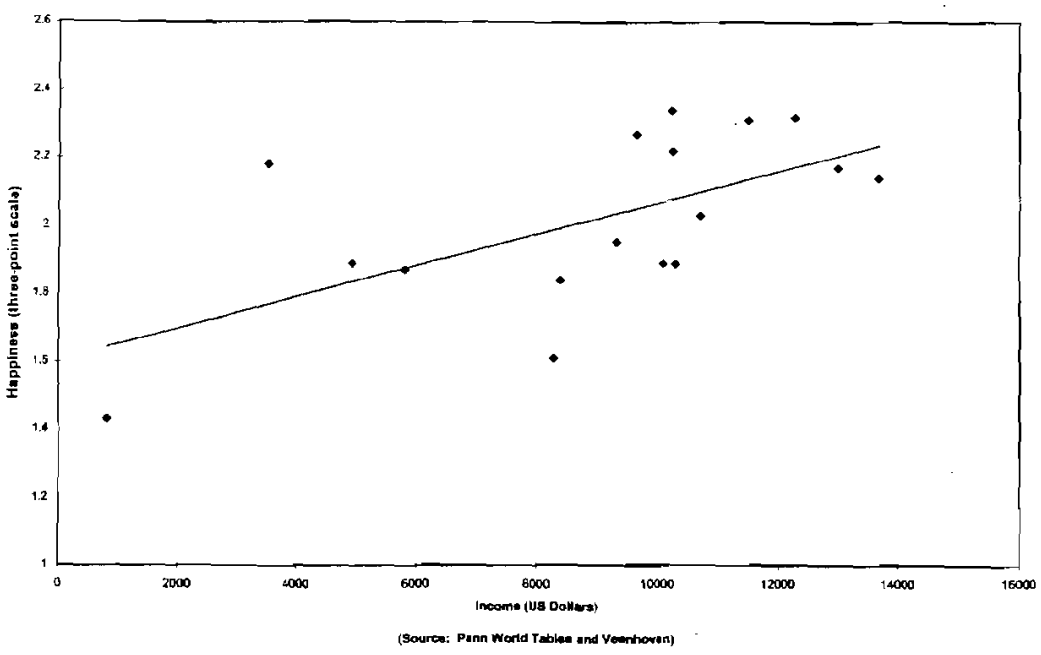

Nonetheless, cross-country polls do present some evidence that rich countries are happier than poor countries. Veenhoven (1994, p. 131) finds a strong and significant correlation between real income per capita and happiness based on polls taken in thirty countries around 1980. Easterlin (1974, p. 105) finds some relationship in a study of fourteen countries in 1960. Using poll data from Veenhoven (1993) and income per capita numbers trom the Penn World Tables. we can see in Figure $l$ and 2 that there does indeed appear to be some relationship between income and happiness, if weak. Both a regression of 1990 happiness against a constant and log 1990 income and a regression of 1975 happiness against a constant and $\log 1975$ income find incone correlated with happiness at one percent significance". However, il the bottom left data point (India) is taken out of the 1975 cross-country regression, the relationship between income and happiness is no longer significant. Splitting the 1990 sample into two groups of income above and below $\$ 8.000$. there is no significant relationship between happiness and income above or below this line ${ }^{10}$.

9. For 1990. $\mathrm{N}=29$. he t-stat on income is 3.74, R-squared is 0.34. For 1975. $\mathrm{N}=17$. the t-stat. on initial income is 3.14 , the R-Squared is 0.40 .

10. For the 1990 regression for countries witt incomes below $\$ 8.000 . \mathrm{N}=12$. the 1-stat. on income is -1.57 (the relationship is, if anything. negalive), the R-Syulred is 0.20 . For the 1990) regression for countries with incomes above $\$ 8.000) . N=17$. the t-stat. on income is $-0.2+$. the R-Squared is 0.00). For the 1975 regression without Indiat, $N=16$, the t-stat. on intial income is 1.19, the R-Squared is 1).199. 
DOES HAPPINESS CAUSE GROWTH?

Figure 2

Happiness Against income Across Countries, 1990

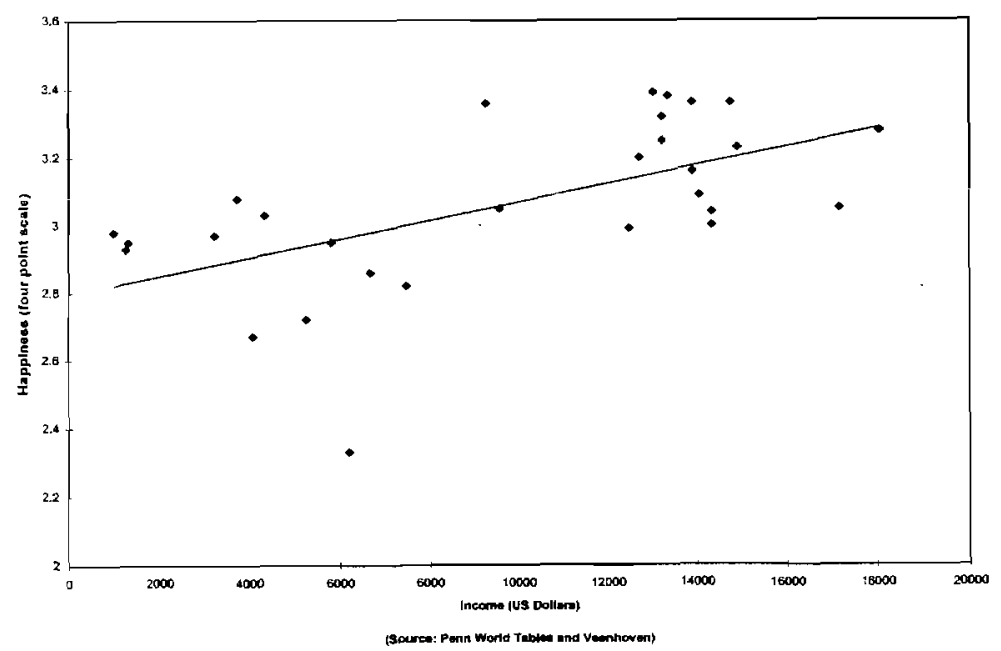

Figure 3

US Happiness Over Time

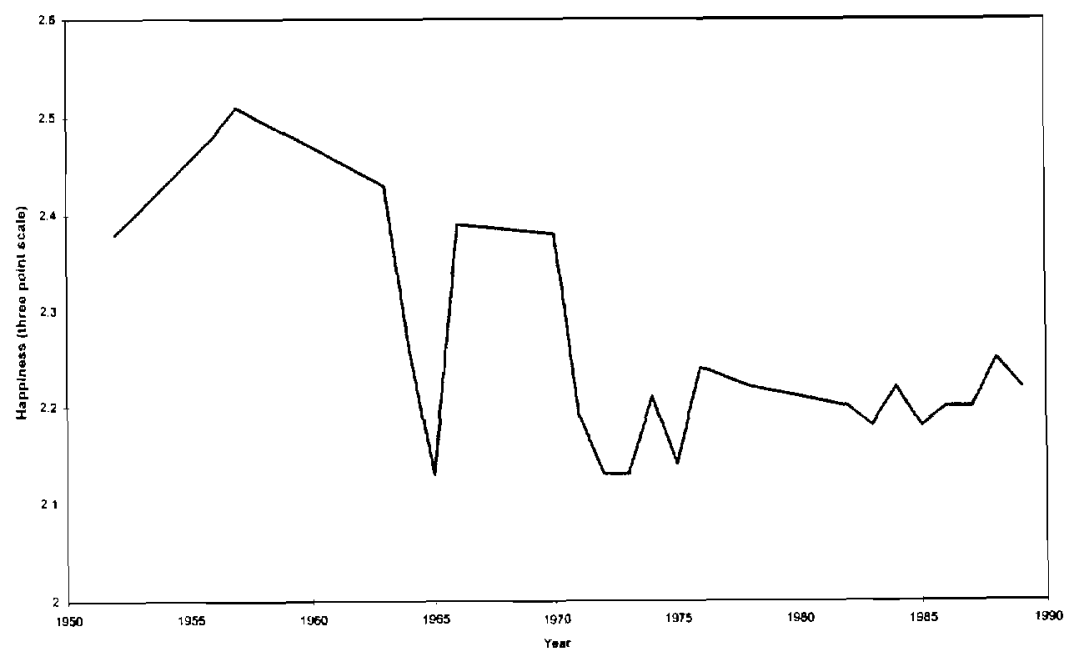




\section{CHARLES KENNY}

Further, there is plentiful evidence that, at least in the now richer countries, there is no relationship between income growth and growth in reported happiness. In Japan, reported happiness remained at almost exactly the same level between 1958 and 1988 (Veenhoven 1994). Over that period, Japanese GDP per capita in constant dollars climbed from $\$ 2.436$ (or about the same as Swaziland's present income per head) to $\$ 13.156$ (Summers and Heston 1991). Easterlin (1995) provides further evidence on the US, Japan and Europe, again suggesting that there is no clear relationship between growth and happiness in these countries.

Table 2

Happiness and Income in Countries

\begin{tabular}{|c|c|c|c|}
\hline & $\begin{array}{l}\text { Coefficient of } \\
\text { income }\end{array}$ & $\begin{array}{l}\text { Coefficient of } \\
\text { income growth }\end{array}$ & $\begin{array}{l}\text { Coefricient of } \\
\text { lagged income growth }\end{array}$ \\
\hline Belgium & -0.00014 k* & -1.469091 & 0.03934 \\
\hline Denmark & -0.0000439 & 0.237897 & -0.012559 \\
\hline France & 0.0000008 & -0.070912 & -0.002201 \\
\hline Ireland & 0.0001180 & 0.314271 & -0.006168 \\
\hline Italy & 0.0000207 & -0.261726 & -0.005931 * \\
\hline Luxembourg & $0.000046^{*}$ & -0.514 .327 & $0.0344 * *$ \\
\hline Netherlands & 0.0000071 & -0.320419 & -0.003219 \\
\hline United Kingdom & $-0.000007+5=$ & -0.970901 & -0.019755 k: \\
\hline United States & $-0.00000273^{\text {w: } 3: k \mathrm{k}}$ & 0.028359 & 0.006634 \\
\hline West Germany & 0.0000220 & 0.729914 & $0.009728 *$ \\
\hline
\end{tabular}

Column 1: Happiness against a constant and income per capita:

Column 2: Happiness growth against a constant and income growth per capita:

Column 3: Happiness against a constant and previous income growth per capita:

(Separate regressions for each country).

* Significint at $10 \%$;

:signiticant at $5 \%$ :

**:k* Significant at $1 \%$

Source: Veenhoven (1995) and Summers and Heston (1991).

Includes all countries with ten or more separate years of data on national happiness (by 3-step polI) and income. 
Looking at reported happiness in the US over time, we have 3-step happiness data from 1952 to 1989. Over that time, US GDP per capita approximately doubled, from $\$ 9.074$ to $\$ 18.095$. As Figure 3 displays, happiness actually dropped over that time by about 0.2 points on a three-point scale (although Oswald 1997, using different data, argues that there is a slight time trend toward happiness in the US). Taking all the countries from Veenhoven (1993) which have results from ten or more three-step happiness polls and income data in the Penn World Tables, I ran separate regressions for each country of happiness against a constant and income, happiness growth against a constant and income growth and happiness against a constant and previous income growth ". The results are reported in Table 2. Happiness is significantly and negatively related to income in three countries, while only positively related in one. Lagged income growth is positively and significantly related to happiness in two countries and negatively and significantly related in two countries. Varying the statistical technique, I ran a pooled regression with fixed effects (a separate constant for each country) and with a common constant (Table 3). In the fixed effects regression, happiness was significantly negatively related to income, and happiness growth was significantly and negatively related to income growth. There was no relationship between happiness and past income growth in the fixed effects regression and a negative relation in the common constant regression. It is possible that there remains a positive utility to absolute income that happens to have been balanced by equal or larger associated negative externalities such as pollution or the process of social modernization. Still, this evidence suggests at least that the utility gained by income in the West is small compared to other determinants of national happiness.

The cross-country data does suggest some link between income and happiness at least between poorer and ticher countries. Such a relationship makes sense in the framework laid out earlier. Clearly, there is a basic level income that is necessary to meet basic animal needs of survival. How large a GNP per capita is enough to ensure such basic needs? Diener and Diener (1995) construct a basic needs fulfillment index based on access to safe drinking water, infant mortality, life expectancy, percent with sanitary facilities and mean daily calorie supply. It is significantly related to income up to a GDP per capita of approximately $\$ 4.000$, but even this rather advanced list of basic needs then loses any significant correlation with income. Ingram (1992) comes to similar conclu-

11. Because polting took place at irregular intervals and I did not want to use overlapping growth data, 'previous growth' is the growth that occurred between the last poll and the poll under investigation - i.e.. it is not a constant-length period. This is only a serious problem if one imagines there is a "happiness business cycle". 
sions, while Easterly (1997) argues that the record of the last thirty years suggests an even weaker relationship than Diener and Diener find. Using an analysis that accounts for country fixed effects, Easterly finds that only 7 out of 50 'quality of life' variables that he tests experience causal growth effects that are positive, significant and more important than exogenous shifts (although he notes that this might be because of long and variable lags between income increases and improvements in quality of life indicators) ${ }^{12}$.

Table 3

The Relationship Between Happiness and Income

Pooled regressions on BEL, DEN. FRA. IRE, ITA, LUX. NLD, GBR. USA, DEU

\begin{tabular}{|c|c|c|c|c|c|c|}
\hline $\begin{array}{l}\text { Dependent } \\
\text { Variable }\end{array}$ & Happiness & $\begin{array}{l}\text { Happiness } \\
\text { Growth }\end{array}$ & Happiness & Income & $\begin{array}{l}\text { Happiness } \\
\text { Growth }\end{array}$ & $\begin{array}{l}\text { Income } \\
\text { Growth }\end{array}$ \\
\hline $\begin{array}{l}\text { Independent } \\
\text { Variable }\end{array}$ & Income & $\begin{array}{l}\text { Income } \\
\text { Growth }\end{array}$ & $\begin{array}{c}\text { Past } \\
\text { Income } \\
\text { Growth }\end{array}$ & $\begin{array}{c}\text { Past } \\
\text { Happiness } \\
\text { Growth }\end{array}$ & $\begin{array}{l}\text { Initial } \\
\text { Income }\end{array}$ & $\begin{array}{c}\text { Initial } \\
\text { Happiness }\end{array}$ \\
\hline \multicolumn{7}{|c|}{ Fixed Effects Regressions } \\
\hline IV Cuefficient & $-1.86 E-05$ & -0.1856 & -0.00079 & 6.089871 & 0.000287 & 9.727875 \\
\hline IV t-stat. & -2.9979 & -2.12082 & -0.51106 & 0.246628 & 0.77 & 1.656368 \\
\hline R-Squared & 0.78 & 0.07 & 0.79 & 0.70 & 0.03 & 0.09 \\
\hline \multicolumn{7}{|c|}{ Common Constant Regressions } \\
\hline Constant & 2.003128 & 0.611035 & 2.148801 & 11435.82 & -0.1279 & 10.30155 \\
\hline Constant t-stat. & 23.13465 & 1.042926 & 99.06455 & 50.25898 & -0.05296 & 1.684288 \\
\hline IV Coefficient & $1.10 \mathrm{E}-05$ & -0.1712 & -0.00683 & -12.9238 & $9.86 \mathrm{E}-06$ & -3.11269 \\
\hline IV t-stat. & 1.459264 & -2.08803 & -2.25093 & -0.30108 & 0.046288 & -1.08798 \\
\hline R-Syuared & 0.02 & 0.04 & 0.05 & 0.00 & 0.00 & 0.01 \\
\hline
\end{tabular}

Source: Veenhoven (1995) and Summers and Heston (1991).

Includes all countries with ten or more years of data on hational happiness (by thrce step poll) and incolne.

12. The seven are child labor rates, calorie incake, protein incake, cars. commercial vehicles, telephones and the share of the botton income cquinile.

16 
Further. even in poor countries there is evidence to suggest that happiness is related to many other things apart from income and its effects on the standard of living. As we have seen, there is no cross-country correlation between income and happiness in a 1990 sub-sample of countries with incomes under $\$ 8.000$ (although this comes with the usual caveats about cross-country studies, and is based on a very small sample). One thing that might explain this is that people in poorer countries often have different. more achievable wants. For instance, Cantril's cross-country study of The Pattern of Human Concerns (1965, p. 164) noted that good health is a very low aspiration in India, despite it being the country in his study with by far the worst health record. Cantril also found no clear relationship between concern for personal or national economic affairs and an objective index of socioeconomic status, and an anecdotal definition of what was required for a decent standard of living that was highly correlated with national income (Cantril 1965. pp. 201 and 223).' Further, there is clearly great importance attached to issues of non-wealth status and caste in India, even at the cost of absolute wealth gains (Basu 1989, p. 668). This, again, is an idea that Adam Smith noted about Britain in the mid-eighteenth Century:

'Honor makes a great part of the reward of all honorable professions. In point of pecuniary gain, all things considered, they are generally undercompensated' (Smith 1910, Book I Ch. X).

It continues to be a factor in modern-day Britain, where millions of legitimate welfare claimants do not make claims, apparently in part because of the stigma attached (Sen 1995, p. 14).

As Aristotle and Smith also noted, and has long been recognized by proponents of the relative income hypothesis, relative wealth does appear to be a significant determinant of happiness. Scitovsky, for example, presents a US poll from 1974 which reports the percentage of people with an income of under $\$ 1.000$ answering that they were very happy was 20 percent. This compares to 53 percent answering they were very happy amongst those with an income over $\$ 15.000$ (Scitovsky 1992, p. 136). This suggests that the marginal utility of relative income remains above zero. In turn, this suggests that taking ten dollars from the rich and giving it to the poor might allow for more people to preserve public decency, at little loss of happiness to the wealthy (especially given how much an individual considers to be a 'good' or 'bad' income is strongly dependent on their own wealth (Van Praag 1993, p. 372. Ng and Wang 1991. pp. $6-7))^{13}$. Indeed. Morawetz's (1979) study of two settlements in Israel found

13. Alhough Easterlin (1974. p. 119) argues that it is quite possible that if inechality was reduced. sensitivity to inequalicy would increase. Lanceling unt the welfare gain. Further. to the extent that happiness is an activity more tham a state. the passive receipt of transfers might well not increase it (Hudson 1996, p. 92). 
that, even after controlling for a range of other possible correlates, the settlement with equal income distribution was significantly happier than the community where incomes varied (although Tomes 1985 found mixed evidence from a study of income distribution and happiness in Canada).

Table 4

Income. Inequality, and Happiness

\begin{tabular}{|c|c|c|c|c|c|c|c|}
\hline \multirow{3}{*}{$\begin{array}{l}\text { Country } \\
\text { Belgium }\end{array}$} & \multirow{3}{*}{$\begin{array}{l}\text { Year } \\
1979 \\
1985\end{array}$} & \multicolumn{2}{|c|}{ GNP per Capita } & \multicolumn{2}{|c|}{ Gini Coefficient } & \multicolumn{2}{|c|}{ Happiness } \\
\hline & & 10.679 & $\uparrow$ & 28.25 & $\downarrow$ & 2.40 & $\downarrow$ \\
\hline & & 11.285 & & 26.22 & & 2. 10 & \\
\hline \multirow[t]{2}{*}{ Denmark } & $1975($ Gini 76$)$ & 10.236 & $\uparrow$ & 31.0 & $\uparrow$ & 2.34 & $\downarrow$ \\
\hline & 1986 (Gini ‘87) & 13.449 & & 33.15 & & 2.13 & \\
\hline \multirow[t]{2}{*}{ France } & 1975 & 10.297 & $\uparrow$ & 38.40 & $\downarrow$ & 1.89 & $\uparrow$ \\
\hline & 1984 & 12.034 & & 37.20 & & 1.91 & \\
\hline \multirow[t]{2}{*}{ Ireland } & 1975 (Gini 73 ) & 5.806 & $\uparrow$ & 38.69 & $\downarrow$ & 1.87 & $\uparrow$ \\
\hline & 1986 (Gini -87$)$ & 7.238 & & 34.60 & & 2.10 & \\
\hline \multirow[t]{2}{*}{ Italy } & 1975 & 8.282 & $\uparrow$ & 39.00 & $\downarrow$ & 1.61 & $\uparrow$ \\
\hline & 1986 & 11.115 & & 33.58 & & 1.82 & \\
\hline Luxembourg & $\begin{array}{l}\text { Insufficient } \\
\text { data }\end{array}$ & & & & & & \\
\hline \multirow[t]{2}{*}{ Netherlands } & 1975 & 10.255 & $\uparrow$ & 28.60 & $\uparrow$ & 2.22 & $\uparrow$ \\
\hline & 1986 & 11.797 & & 29.68 & & 2.36 & \\
\hline \multirow[t]{2}{*}{ UK } & 1965 & 7.679 & $\uparrow$ & 24.30 & $\uparrow$ & 2.49 & $\downarrow$ \\
\hline & 1986 & 11.726 & & 27.80 & & 2.08 & \\
\hline \multirow[t]{2}{*}{ USA } & 1952 & 9.074 & $\uparrow$ & 35.10 & $\uparrow$ & 2.38 & $\downarrow$ \\
\hline & 1989 & 18.095 & & 38.16 & & 2.22 & \\
\hline \multirow[t]{2}{*}{ West Germany } & 1978 & 11.375 & $\uparrow$ & 32.06 & $\uparrow$ & 1.94 & $\uparrow$ \\
\hline & 19.84 & 12.302 & & 32.20 & & 1.97 & \\
\hline
\end{tabular}

Sources: Deininger and Squire (1996), Veenhoven (1995) and Summers and Heston (1991). 


\section{DOES HAPPINESS CAUSE GROWTH?}

Using inequality data from the Deininger-Squire data set, Table 4 provides evidence for such a link from the study countries (excluding Luxembourg, for which there was insufficient inequality data). Taking the earliest and latest year for which the data sets provide Gini and happiness scores, a tising Gini coefficient (showing increased inequality) sees falling happiness in three countries and rising happiness in two. A falling Gini coefficient sees rising happiness in three countries and deciining happiness in one. In other words, six countries confirm a negative relationship between inequality and happiness, and three contradict it. Two of the three that contradict the relationship have the two smallest changes in Gini coefficients in the sample.

This evidence does not allow for us to determine between the modern arguments for the relative income hypothesis and the 'traditional' arguments involving social interaction presented by Smith and Mill. Some evidence for the traditional argument relating happiness and morality does appear when we ask, does hedonic happiness lead to growth? The evidence is, admittedly, weak. In a seventeen-country regression of income growth 1981-90 against a constant and initial income and happiness based on data from Veenhoven, initial happiness was significantly (at 5 percent) negatively related to growth. On the other hand, Table 3 reports a tixed effects pooled regression of income growth against initial happiness, free from cultural biases, which suggests there is a positive relationship, significant at about 10 percent. Certainly, if there is any causal relationship in rich countries, it appears to run from happiness to growth, not vice-versa.

\section{WHY GROW?}

If there is indeed no relationship between happiness and growth, this leads to the question, why grow? Clearly, growth remains important amongst the poorest countries. Growth at this level is vital to create the animal conditions of survival necessary to pursue happiness. How much is enough? The break in the 1990 poll data suggests that there is no relationship between income and happiness after approximately $\$ 8.000$ per capita. Murray $(1988$, p. 65) suggests that the link between happiness and wealth has broken down by the time a GNP per capita of about $\$ 5.000$ (in 1978 US dollars) has been reached (approximately the same level as the breakdown of the link between Diener and Diener's basic needs fulfillment index and GDP per capita). Japan has not grown happier since its income per head was $\$ 2.436$, while the 1975 poll data reported earlier suggests no 
significant relationship above $\$ 1.000$ per capita. Even if we take the upper bound of $\$ 8.000$, this still suggests that at least OECD governments should turn their attentions from growth to other things ${ }^{14}$. As Galbraith (1984) put it,

to furnish a barren room is one thing. To continue to crowd in furniture until the foundation buckles is quite another".

What other things these are depend on the ways we can still add to the sum of the utilities of all. One way to achieve this might be to alter relative wealth. One of the problems mentioned with GNP per capita at the outset is that the marginal utility of a doliar might be higher to those at the bottom of the Gini curve than it is to those at the top. Further, we have seen more support for a relationship between happiness and equality, and this suggests a possible role for taxing the luxuries of the wealthy so that

'the indolence and vanity of the rich is made to contribute in a very easy manner to the relief of' the poor: (Smith 1910$)^{1 \overline{5}}$.

The continuing importance of relative wealth in determining happiness suggests the presence of a tragedy of the commons. In a growing economy, a benevolent state should penalize those activities that increase absolute personal wealth at the cost of general happiness. For example, we have (weak) evidence that leisure and happiness are related, based on calculations from the 1990 World Values Survey data reported in Veenhoven (1993) and hours worked per employee data from Maddison (1995). Those four countries with data that had av-

14. To some extent. they alleady have turned their attention to other things. The expansion of class consciousness during the Nineteenth and Twentieth centuries is a sign of the growing importance of considerations of relative wealth. This compares to relations in many developing countrics that run across classes and are designed to preserve or enhance absolute standards of living. Popkin s ( 1979) 'rational peasant' may in fact be the inore 'rational' (in the sense of fitting the thaditional income-maximizing condition) individual than the rich Western consumer on which the model is based.

15. It might be argued that international communication is making intra-national comparison increasingly irrelevant as a basis for measuring relative wealth. But it might also be that the nation is too big a unit to judge relative wealth. As noted earlier. Cantril's and others" work suggests that people judge wealthiness largely relative to their own income (the poor define very tich as an income level a traction of that level defined by the rich. This suggests that personal associat tion matters far more than international comparison in shaping a person's feelings of relative weilth. Even if. however. people in developing countries have begun to judge their wealth relalive to people in the OECD. this is only a reason for growth in the OECD to be a ciluse of global misery. is international inequalities are increased. This is certainly not an internationalist justification for continued Western economic growth. 
DOES HAPPINESS CAUSE GROWTH?

erage work hours per employee of under 1.500 hours a year were five percent happier than those six countries with average work hours over 1.600 a year. Yet, while leisure time has expanded in richer countries, if productivity had continued to rise while incomes per person had remained steady, leisure could have increased far faster. This suggests there might be a role for government in forcing people to take holidays. Left up to themselves, people will continue the struggle to ensure stable or increasing relative wealth, abandoning leisure in the pursuit of the Jonses. Unless we force both the Jonses and their neighbors to take holidays, they will both expend valuable leisure time in ensuring that their absolute wealth keeps up.

\section{CONCLUSION}

This paper has not argued that economic growth in developed countries is inherently bad - although there are obvious environmental concerns over its longterm sustainability, and there do appear to be negative externalities attached. Instead, it has argued that there is no particular reason to think that growth is always good. Growth in wealthy countries fails to create what it is supposed to create: greater utility ${ }^{16}$.

I have argued that this is because of a fundamental and widespread misconception of the major causes of happiness. To the extent that there is a link between income and happiness in rich countries, it is connected to relative, not absolute wealth. This has important theoretical implications. For example, if relative wealth is more important than absolute wealth, activities that are detrimental to the national income but neutral (or less harmful) to a particular individual become 'rational' for that individual. A positive implication is that, if utility is to be gained from honor, badly paid civil servants do not have to be motivated purely by opportunities for rent-seeking.

Of course, the weak relationship between absolute wealth and utility also has important policy implications. A US worker opposed to NAFTA because it is increasing relative income disparities even as it increases output might hold the correct view from a utility-maximizing standpoint. Governments that enforce

16. This does raise the question: why is it such a widely held view that growth will baise utility? A neo-Marxist might argue that it is because a concentration on economic growth leaves questions ibout economic distribution unasked. A Weberian might point to the Protestant ethic. or variations thereupon. The Weberian idea of a concern to show one is saved lïts well with a globalized tragedy of the commons. Rapid economic growth is the sign of a chosen people and that a country is rich shows its citizens are saved. We grow. then. for tear of damnation. with all the altached misery that such a worldview holds. 
maximum working hours provisions might, again, be increasing utility. Even for poorer countries where there almost certainly remains a causal relationship from growth to happiness, the evidence presented here has implications. There is some evidence to suggest that a country that fosters happiness and stronger societies directly, through respect for basic human rights (found a significant determinant of happiness by Veenhoven 1994, p. 136), or attempts to limit inequality, might grow faster. Certainly, there is little evidence that they grow more slowly ${ }^{17}$. Whatever the nature of causality between happiness and a stronger, inclusive, society, and the exploration above suggests it might be bi-directional, actions that improve happiness and the strength of social interaction are good in their own right and might have the added advantage of encouraging growth. There is no logic to putting off these policy changes until the nation can 'afford' them.

Overall. the analysis in this paper suggests that the answer to the question 'which causes which?' is that both might have a marginal impact on the other. A certain level of economic well-being is a necessary condition for happiness, but there is plentiful evidence to suggest that economic well-being is far from sufficient. Once a certain standard of living is attained, the relationship between growth and happiness breaks down. On the other hand, happiness appears to be far more complex than is often assumed when we talk about utility. Being fulfilled involves relations with a wider society that suggest there might be a causal relationship from happiness to growth. This is unimportant in wealthy countries, where the end of happiness has long since separated from the means of economic growth. In poorer countries, however, it suggests that there is no necessary conflict between increasing present utility and looking forward to even greater urility in the future.

17. Although it should be noted that the evidence on a positive relation between civil rights and growth is weaker than hats become fashionable to assume. Brunetti's (1997) survey finds that only lour of seven papers looking at political violence find it significant relationship with growh. The evidence on inequality and growth also remains hotly debated (Deininger and Stpuire 1990). 


\section{DOES HAPPINESS CAUSE GROWTH?}

\section{REFERENCES}

Abramovitz. Moses (1958). The Welfare Interpretation of Secular trends in National Income and Product, in: Moses Abramovitz et al. (eds.), The Allocation of Economic Resources. Stanford, CA: Stanford University Press.

Aristotle (1962). The Politics. London: Penguin.

Aristotle (1980). The Nichomachean Ethics. New York: Oxford University Press.

Atkinson, A. (1997). Bringing Income Distribution in from the Cold, The Economic Journal. 107: 297-321.

Bannock, G., R. Baxter and E. Davis (1987). The Penguin Dictionary of Economics. London: Penguin.

Basu, Kaushik (1989). A Theory of Association: Social Status. Prices and Markets, Oxford Economic Papers. 41: 653-671.

Blanchflower, David and Andrew Oswald (1992). Entrepeneurship, Happiness and Supernormal Returns: Evidence from Britain and the US. NBER Working Paper No. 4228.

Bourguignon. François (1996). Equity and Economic Growth: Permanent Questions and Changing Answers?, Background paper for the 1996 Human Development Report. UNDP.

Brunetti. A. (1997). Political Variables in Cross-Country Growth Analysis, Journal of Economic Survevs. 2: 163-190.

Cantril, Hadley (1965). The Pattern of Human Concerns. New Brunswick: Rutgers.

Clarke, George (1995). More Evidence on Income Distribution and Growth, Journal of Development Economics. 47: 403-427.

Dagum, Camilo (1990). On the Relationship Between Income Inequality Measures and Social Welfare Functions. Joumal of Econometrics. +3: 91-102.

Diener, Ed and Carol Diener (1995). The Weatth of Nations Revisited: Income and the Quality of Life, Social Indicators Research. 36: 275-286.

Deininger. Klaus and Lyn Syuire (1996). A New Data Set Measuring Income Inequality, World Bank Economic Review. 10: 565-591.

Dusenberry, J. (1949). Ancone, Saving and the Theory of Consumer Behaviour: Cambridge: Harvard University Press.

Easterlin. Richard (1974). Does Economic Growth Improve the Human Lot?, in: P. David and M. Reder (eds.), Nations and Households in Economic Growth. New York: Academic Press.

Easterlin. Richard (1995). Will Raising the Incomes of All Increase the Happiness of All?. Joumal of Economic Behaviour and Organization. 27: 35-47.

Eusterly, William (1996). Why is Africa Marginal in the World Economy?, in: G. Maasdorp (ed.), Can South and Southern Africa become Globally Competitive Economies. London: Macmillan.

Easterly, William (1997). Life During Growth. mimeo. World Bank.

Fay, Marianne (1993). Illegal Activities and Income Distribution: A Model with Envy, mimeo, Columbial University

Frank, Robert (1997). The Frame of Reference as a Public Good. The Ecomomic Journal. 107 $1832-1847$.

Fukuyama, Francis (1995). Social Cupital and the Global Econony, Foreign Affarrs. 74. 5.

Galbraith. John (1984). The Affluent Socier: New York: Mentor.

Grenato. Jim, Ronald Inglehart and David Leblang (1996). Cultural Vilues. Stable Democracy, and Economic Development: A Reply, American Jom of Polifical Science. 40: 680-696.

Helliwell. John (1996). Economic Growth and Social Capital in Asia. NBER Working Paper 5470.

Hirsch. Fred (1978). Social Limits to Growth. Cambridge: Harvard University Press.

Hudson. Deal (1996). Happiness and the Limits of Sutisfaction. Lanham. MD: Rowman and Littlefietd.

Ingram. Gtegory (1992). Social Indicators and Productivity Convergence in Developing Countries, Wortd Bank Policy Research Working Paper 894.

Jackman. Robert and Rass Miller ( [996). A Renaissance of Political Cuiture, American Journal of Political Science 40: 032-659 


\section{CHARLES KENNY}

Kenny. Anthony (1992). Aristotle on the Perfect Life. Oxford: Clarendon.

Linder, Steffan (1970). The Harried Leisure Class. New York: Columbia University Press.

Maddison, Angus ( 1995). Monitoring the World Econony 1820-1992. Paris: OECD.

McGill, V. (1967). The Idea of Happiness. New York: Praeger.

McMylor, P. (1994). Alisdair Mac'Intrre: Critic of Modernity: London: Routledge.

Mill. John Stewart ( 1980). On Libertw: Indianapolis: Bobbs-Merrill.

Mishan, E. (1967). The Costs of Economic Growth, London: Pelican.

Morawitz. David (1979). Income Distribution and Self-Rated Happiness: Some Empirical Evidence, The Economic Joumai. 87: $511-522$.

Murray, Charles (1988). In Pursuit of Happiness and Good Government. New York: Simon and Schuster.

Myers, David and Ed Diener (1996). The Pursuit of Happiness. Scientific Anerican. 272: 70-72.

Narayin, Deepa and L. Pritchett (1996). Cents and Sociability: Household Income and Sucial Capital in Rural Tanzania. mimeo. The World Bank.

Ng, Yew-Kwang and Jianguo Wang (1991). Relative Income. Aspiration. Environmental Quality, Individual and Political Myopia: Why May the Rat-Race for Material Growth be WelfareReducing?, Monash University Department of Economics Seminar Paper 7/91.

Oswald, Andrew (1997). Happiness and Economic Performance. The Economic Joumal. 107: 1815-1831.

Perotti, Roberto (1995). Growth. Income Distribution and Democracy: What the Data Say, mimeo, Columbia University.

Pigou, A. (1912). Wealhh and Welfare. London: Macmillan.

Popkin, Sam (1979). The Rational Peasant: The Political Economy of Rural Sociery in Vietnam. Berkeley: University of California Press.

Pritchett. Lant and Larry Summers (1996). Wealthier is Healthier, Journal of Human Resources. 31: $842-868$.

Putnan. Robert with R. Leonardi and R. Nanetti (1993). Making Democracy Work: Civic Traditions in Modem ltaly: Princeton: Princeton University Press.

Rothschild. Emma (1995). The Debate on Econonic and Social Security in the Late Eighteenth Century: Lessons of a Road Not Taken. Development and Change. 27: 331-351.

Russell. Bertrand (1930). The Conquest of Happiness. New York: Horace Liveright.

Scitovsky, Tibor (1992). The Joyless Economy (Revised Edition). New York: Oxford University Press.

Seabright. Paul (1997). The Effect of Inequality on Collective Action, mimeo, The Workd Bank.

Sen. Amartya (1980). Equality of What?, in: S. McMurrin (ed.). Tenner Lectures on Human Values, i. Cambridge: Cambridge University Press.

Sen, Amurtya (1985). The Standard of Living. Cambridge: Cambridge University Press.

Sen. Amattya (1992). Inectuality Reexamined. Cambridge: Harvard University Press.

Sen. Amartya (1995). Rationality and Social Choice, Anerican Economic Revicw. 85: 1-24.

Sunith, Adam (1910). The Wealth of Nation.s. London: J.M. Dent.

Smith. Adam (1982). The Theor of Mord Sentiments (Glusgow edition). Indiandapolis; Liberty Press.

Stabile, Donald (1996). Theories of Consumption and Waste. Journal of Economic /ssues. 30 : $685-699$.

Summers, R. and A. Heston (1991). Penn World Table (Mark 5): An Expanded Set of International Compurisons, 1950-1988, Quarter/y, Journal of Economics. 106: 327-368.

Svennson, J. (1994). Investment. Property Rights and Political Instability: Theory and Evidence. mineo, Institute for International Economic Studies, Stockholm.

Tomes, Nigel (1985). Intome Distribution. Happiness and Satisfaction. Department of Economies University ol Western Ontario Research Report No. 8507.

Van Praug. B.M.S. (1993).The Relativity of the Welfare Concept. in: Martha Nussbaum and Amartya Sen reds.1, The Qmality of Life. Oxford: Clarendon: $362-+16$. 


\section{DOES HAPPINESS CAUSE GROWTH?}

Veenhoven, Ruut (1993). Happiness in Nations: Subjective Appreciation of Life in 56 Nations: 1946-1992. Rotterdam: RISBO.

Veenhoven. Ruut (1994). Is Happiness A Trait?. Social Indicators Research. 32: 101-60.

Veenhoven. Ruut (1995). World Database of Happiness. Social Indicators Research. 34: 299-313. World Bank (1996). World Tables. Washington, DC: World Bank.

\section{SUMMARY}

Although there are many accepted faults with GNP per capita as a measure of the utility gained from wealth. most commentators would still argue that an increuse in GNP per capita will have positive effects on total utility outweighing any negative externalities. Taking lessons from a conception of the nature and causes of llappiness that laarks back to Adam Smith and the original Utilitarians, this paper argues that increases in absolute income should have little effect on happiness in rich countries, and that there might instead be channels linking happiness causally with growth. Using time series evidence from happiness polls in ten weal thy countries, the paper finds no support for a causal link from growth to happiness. weak support for a reverse causation and further (weak) support for links between national equality and happiness and leisure time and happiness. The paper concludes by offering some consequences of this for theory and policy.

\section{ZUSAMMENFASSUNG}

Obwohl das BSP pro Kopt als Mass für den Nutzen von Wohlstand viele allgemein anerkannte Fehler aufweist, würden die meisten Kommentatoren nach wie vor behaupten, dass eine Zunahme des BSP pro Kopf eine positive Wirkung iuf den Gesamtnutzen hat, die alle negativen Externalitäten übersteigt. Autbauend auf einer Vorstellung von der Natur und den Lrsuchen von Glück, die bis zu Adam Smith und den ursprünglichen Utilitarismus zurückreicht, argumentiert dieser Artikel, dass eine Zunahme des absoluten Einkommens wenig Auswirkungen auf Glick in den teichen Ländem hat. Statrdessen könnten aber Kann̈le existieren. die Glück kausál mit Wachstum verbinden. Die Auswertung von Zeitreihen ius Umiragen über Glück und Zultriedenheit in zehn reichen Lïndem unterstuitzt diese These nicht, ergibl aber schwache Beweise für den umgekehrten Zusammenhang und weitere (schwache) Beweise für einen Zusammenhang zwischen Gleichheit und Glück bzw. Freizeit und Glück. Der Schluss des Papiercs zieht daraus Konsequenzen für Theorie und Politik.

\section{RÉSUMÉ}

Bien que les défauts de la mesure de l'utilité de la richesse par le PIB par tête soient largement reconnus et acceptés. lia plupart des spécialistes soutiennent toujours l'jdée selon laquelle les effets positif's d'une augmentation du PIB par tête sur l'urtilité totale l'emportent largement sur ses externalilés négatives. En se basunt sur une conception de la nature et des causes du bien-ître qui remonte ì Adaun Smith et aux premiers utilitaristes, cet article soutient la thèse selon laquelle une augmentation du revenu absolu a peu d'effets sur le bien-être des pays riches, et que. inversement. il existerait peut-être cles voies par lesquelles le bien-ètre a des effets sur la croissance. En metlant en valesur les résultats de l'analyse de séries de donnees recueillies à travers des sondages sul le bien-être dans dix pays riches, cet article montre qu il n y a pas de rapport causal entre la croissance et le bienître, que le rapport causall entre bien-être et croissilnce est faible. de même que ceux entre égalité nationale et bien-être, et loisirs et bien-être. Cet article conclut en offirant quelques conséquences de ces résultats pour lit théorie et les politiques it mettre en oenvre. 